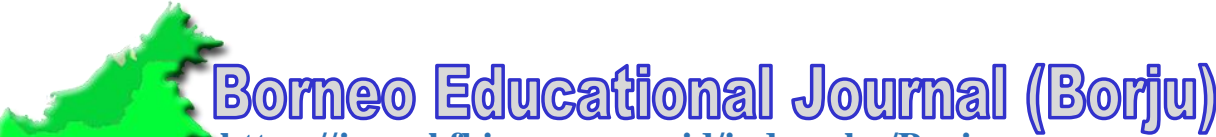 \\ https://jurnal.fkip-uwgm.ac.id/index.php/Borju
}

E-ISSN: 2655-9323

August 2020, Vol.02 No.02

\section{Teacher's Strategies in Teaching English Speaking to Young Learners}

\author{
Nia Florentina Robert ${ }^{1}$, Widi Syahtia Pane ${ }^{2}$ \\ Universitas Widya Gama Mahakam, Indonesia ${ }^{1,2}$ \\ Email Correspondence: niarobert98@gmail.com
}

\begin{abstract}
In teaching and learning process strategy is an activity that should be done both teacher and learner in order to get learning activity become effective and efficient. In short, teaching strategies are very important since they determine the success of teaching process. Strategies used by teachers should be interesting and can capture students' attention. Some of the strategies used in teaching speaking are such cooperative activities as role-play, creative tasks, and drilling [1].

This article report a qualitative study that find out teacher's strategies in teaching English speaking to young learners in junior school. Two junior school teacher in SMP Purnama were participated in this research and data were collected through interviews based on a case study design.

The result of this study indicated the technique employed by the teacher in teaching speaking were so various such as role play, storytelling, social strategy and discussion. Teachers at SMP Purnama use more than one teaching strategy same like explanation above. This strategy helps students in an easier, faster, and more fun way mastering vocabulary so that it greatly supports the improvement of students' speaking skills.

The teachers chooses a strategy based on the principles of teaching speaking. The teacher uses several strategies to help students are more motivated to learn and can add to their new vocabulary.
\end{abstract}

Keywords: Teacher's Strategies; Speaking; Young learners; Teaching Speaking

\begin{tabular}{|c|c|c|}
\hline DOI & $:$ & https://doi.org/10.24903/bej.v2i2.627 \\
\hline Received & : & June 2020 \\
\hline Accepted & : & July 2020 \\
\hline Published & : & August 2020 \\
\hline $\begin{array}{l}\text { Copyright and } \\
\text { License }\end{array}$ & : & $\begin{array}{l}\text { Authors retain copyright and grant the journal right of first publication with the } \\
\text { work simultaneously licensed under a Creative Commons Attribution } \mathbf{4 . 0} \\
\text { International License that allows others to share the work with an acknowledgment of } \\
\text { the work's authorship and initial publication in this journal. } \\
\text { cc (i) }\end{array}$ \\
\hline
\end{tabular}




\section{INTRODUCTION}

There are four skills that should be mastered by students in learning English. Speaking, listening, reading, and writing. In presenting English, especially speaking, the teacher should be creative in choosing materials and able to stimulate the students' interest. Teachers need to manipulate several strategies to support the teaching and learning process. Teaching English to young learners or students is very much different from teaching adults in a way that they are often more active and adaptable than adults. Based on the researchers experience while studying in junior high school, most junior high school students cannot speak English. Furthermore, those who graduate from junior high school do not have sufficient ability to speak English because teaching English in Indonesia is considered unsuccessful. That happens because of many factors, one of which is the teacher's strategy and teachers' experience.

The teacher's strategy gives a lot of influence on the students' conversation. Teacher strategies will help students speak mastery. The level of speaking of students is also influenced by teacher strategy in speaking. Now all teachers have strategies to improve students' speaking abilities. At the school that researcher already choose, have two English teacher that has different teaching experience based on year their start teaching. According to [2] a teacher who has a long teaching experience or a lot, in the sense that he has had a relatively long working period, will have a high level of ability / work performance as a teacher. This is very reasonable, because as long ason duty as a teacher by itself there will be a learning process within the teacher itself, both "learning how to teach well" and "learning how to learn well". Therefore it is not an exaggeration that it finally appearedthe phrase "Experience is a good teacher". Based on the long working period the teacher gets the opportunity to streamline learning activities by making progress notes for their students so that they can make program adjustments they need in learning next.

However, teaching experience should not be measured solely by the length of teaching. Because these two terms have different meanings. Experience teaching with professional values that are expected by the more experienced the teacher teaches, the professionalism of the teacher in teaching is also good, while the length of teaching is related to time, so it is not certain that teachers who have teach for a long time have a good teaching professionalism.

\section{METHODOLOGY}

This research is qualitative research, has focuses in teacher's strategies in teaching English speaking to young learners. Case studies is used to undertake this study which more focus to explore deep process of event or activity [3]. Researcher take case studies as the 
research design because it is the most appropriate design to find out teachers strategies in teaching English speaking to young learners. Researchers have conducted this research in a predetermined place because this study uses interviews through the zoom application, which means the researcher does not conduct this research in school. The place that has been determined is a suitable and quiet place for researchers to conduct interviews through the zoom application. Every participant has been interviewed online and both the interviewer and the interviewee have prepared themselves in an isolated and quiet environment, free from noise distractions. Participants have been interviewed individually and information, responses and observations from other participants were not shared.

Researcher chooses junior school teacher as research subjects because they will face more challenges to teach junior school children (12-13 years old). The teachers has the same education but teach in the different class in SMP Purnama 1 Sendawar. Researcher used interview as the main instrument in collecting data. According to [3], qualitative researcher are the one who gather the information in collecting data by using an instrument. This study use semi structured interview (Zoom application) to find out teacher's strategies in teaching English speaking to young learners.

Interviews were conducted through a zoom application to obtain more in-depth and comfortable information to interview participants who were hesitant to speak directly. The data collection procedure is based on the following steps:

1. Meeting with the staff and tutor to prepare and conduct the research activity.

2. Asking a permission to the principal of the institution (course).

3. Arranging the schedule for interview.

4. Making some questions for interview.

6. Interviewing the teachers

7. Taking notes during an interview section.

After collecting the data by conducting interview, the next step will be done by the researcher is analyze the data. The steps of analyzing the data were described in the followings:

1. Reviewing the data based on interview.

2. Analyzing the data from interview based on purpose of study.

3. Classifying all data from interview result.

4. Drawing the conclusion based on the analyzed data. 


\section{FINDINGS}

This part presents 6 questions in semi-structured interviews to answer the research questions in this study.

\subsection{How long have you been teaching?}

Teacher 1: I have been teaching at SMK and SMP Purnama starting 3 months face-toface and 5 months online.

Teacher 2: I have been teaching at SMK and SMP Purnama starting from 6 years ago.

It shows they have different experience in teaching as an English teacher, teacher 1 is a fresh graduate and start teach from 9 months ago. Teacher 2 already start teach from 6 years ago.

3.2. What kind of strategies do you use in delivering lessons, especially speaking lessons to students?

Teacher 1: The first is Social strategy for example, $i$ explain in front of the students and after that discussion strategy For example, my students do not understand what they read and what they hear, so we discuss one by one between me and my students because if they are the same age they do not necessarily understand each other.

Teacher 2: The strategies $i$ usually use in class, especially speaking, are role playing and then story telling

The statement shows that the teachers 1 used social strategy and discussion in teaching speaking, different from teacher 2 used role play and storytelling strategies or methods commonly used by teachers in teaching.

\subsection{How do you implement your teaching strategies to students?}

Teacher 1: The implementation I use is that we usually learn while playing, but this is more for junior high school students while it is different for senior high school students. At junior high school, I applied the role play method after that, storytelling and conversations.

Teacher 2: In terms of speaking learning, I usually implement it by conversation. We have conversations using simple, short and clear sentences to students.

The statement above explain that teacher 1 using more act to deliver the lessons playing while learning, teacher 2 used often way that every teacher used in teach using simple conversation. 


\subsection{What are the problems in teaching English speaking to young learners?}

Teacher 1: The problems that I often find are children who have poor vocabulary, sometimes they mispronounce there are have a wrong words but i still help them fix the words, and grammar errors. Not only speaking but indeed this English lesson is difficult for children to understand, especially children who are remote and my area is one that is remote so it is a little difficult to explain to children especially when asked to speak English they cannot immediately understand so I have to explain using Bahasa.

Teacher 2: The problem of teaching speaking, when I teach speaking to young students, I often see them with poor vocabulary usually, because many young students don't know the objects around them.

It shows there have a lot of problem when teaching speaking, what is often found is that students do not master vocabulary well.

\subsection{What did you do when you face the problems? How did it work? Is it success or failed?}

Teacher 1: As I explained earlier, many students have difficulty learning English so i use discussion strategies if they don't know I tell or I give assignments such as memorizing, for example, there are English words that they don't know I give assignments to memorize so they know better and that's more effective in my opinion and it works.

Teacher 2: When I met the students I found problems in the lack of vocabulary, I usually did repetition of the material so that the students understood the material, it means I repeated the conversation material, the simple sentence was short and clear, I repeated it once or twice so that the students understood the material I delivered

The statement above shows that teacher 1 give students memorizing assignment and so far its work and students' abilities have improved even more. Teacher 2 used repetition materials or discuss deeply every single materials that students hard to understand and it works.

\subsection{Can you describe the condition in the class when you facing the problems?}

Teacher 1: When the children have difficulty understanding the lesson, the conditions in the classroom remain calm and they will ask questions or discuss with me one by one or in groups.

Teacher 2: In class, of course, we find a problem with students, sometimes the student feels ashamed, not confident and passive when having a conversation when I find a problem like 
that, of course the student becomes tense so I dilute the problem in the class so that how do we trigger the student to be active, usually I do games like the game of the alphabet then guess objects and arrange words, of course it's in English context. Why I usually do this of course to improve children's vocabulary so that learning in the classroom is not tense and passive.

It shows that every students have their own difficulty to understand the lessons and their often passive in the class so to facing the problem teachers more act and more creative to increase students' ability.

\section{DISCUSSION}

The discussion focused on the strategies that are applied and how their implementation the strategies in teaching English speaking to young learners.

\subsection{How long teachers have been teaching.}

According to [2] a teacher who has a long teaching experience or a lot, in the sense that he has had a relatively long working period, will have a high level of ability / work performance as a teacher. This is very reasonable, because as long ason duty as a teacher by itself there will be a learning process within the teacher itself, both "learning how to teach well" and "learning how to learn well". Therefore it is not an exaggeration that it finally appearedthe phrase "Experience is a good teacher". Based on the long working period the teacher gets the opportunity to streamline learning activities by making progress notes for their students so that they can make program adjustments they need in learning next.

\subsection{Kinds of strategies the teachers used.}

From the research finding, the teaching technique employed by the teacher in teaching speaking were so various such as role play, storytelling, social strategy and discussion [1] . Based on a variety of teaching strategies, the researcher concluded that the above teaching strategies were relevant to support students' speaking ability. Teacher strategy in teaching English speaking is very important for students. Teachers at SMP Purnama use more than one teaching strategy. This strategy helps students in an easier, faster, and more fun way mastering vocabulary so that it greatly supports the improvement of students' speaking skills. 


\subsection{How the implementation of teaching strategies.}

To increase student motivation in learning in English, the teacher motivates students to speak in class and tells students not to worry if they make mistakes. The teacher creates a good relationship between teacher and students. So that it makes students feel comfortable in the classroom and also students enjoy when the teacher provides explanations. If students feel comfortable and enjoy the lesson, they will be more active and more receptive the material from the teacher. Teachers also provide motivation and reinforcement to students. The teacher explains the material slowly and translates some difficult words to students, besides that students also pay attention to the teacher. Thus, the students can understand the vocabulary, not only memorizing but also understanding each vocabulary [4].

\subsection{The problems in teaching English speaking.}

Based on the interview was done by the researcher, there were some problems that faced by the teachers in the implementation of teaching English speaking. The problem is students low motivation in learning English, the students has low confidence in practicing English and students feel hard to learn vocabulary. [4] said that factors that cause student learning difficulties, internal factors. (1) Physiological factors, (2) Psychological factors, (3) Motivation, (4) Ego. External factors. (1) Family factors, (2) School environmental factors.

\subsection{Problem solving when facing the problems.}

The solutions found by the teacher in solving the problems are, teacher 1 give students memorizing assignment and so far its work and students' abilities have improved even more [5]. Teacher 2 used repetition matery or discuss deeply every single matery that students hard to understand and its works [6]. 


\subsection{Teachers describe the condition in the class when facing the problems.}

Every students have their own difficulty to understand the lessons and their often passive in the class so to facing the problem teachers more act and more creative to increase students' ability. [7] said effective classroom management is the teacher's ability to build a learning environment that is conducive to increasing student involvement and participation so that optimal learning outcomes can be achieved.

\section{CONCLUSION}

The first there were the conclusions of the research findings is the strategies of teaching speaking that the teacher used were role play, storytelling, social strategy and discussion. The second is the implementation of teacher strategies, teacher 1 implement learn while playing and applied the role play method after that, storytelling and conversations. Teacher 2 implement it by conversation. Conversations using simple, short and clear sentences to students. The teachers chooses a strategy based on the principles of teaching speaking. The teacher uses several strategies to help students are more motivated to learn and can add to their new vocabulary.

\section{REFERENCES}

[1] A. G. Anjaniputra, “Teacher's Strategies in Teaching Speaking to Students at Secondary Level," vol. 1, no. 2, 2013.

[2] Sahari, "Pengaruh Pendidikan, Pelatihan, dan Pengalaman Mengajar terhadap Profesionalisme Guru Di SMAN I Likupang,” J. Pendidik. Islam Iqra, vol. 9, no. 1, pp. 10-11, 2015.

[3] J. W. Creswell, Qualitative Inquiry and Research Design Choosing among Five Approaches, 3rd ed. London: SAGE Publication Ltd, 2013.

[4] Munirah, "Peranan Guru dalam Mengatasi Kesulitan Belajar Siswa," Pendidik. Agama Islam, vol. 3, no. 2, pp. 12-14, 2018.

[5] T. Y. Hardjosoesanto and Siswanto, "Pengaruh belajar dengan cara menghafal terhadap mengingat kosakata dalam bahasa inggris," Psikodimensia, vol. 13, no. 1, p. 3, 2014.

[6] Elinawati, "Penerapan Model Pembelajaran Auditory Intellectually Repetition (AIR) terhadap Hasil Belajar Kognitif Siswa," Sainsmat, vol. 7, no. 1, p. 4, 2018.

[7] S. Junita W. Arfani, "Manajemen Kelas yang Efektif: Penelitian di Tiga Sekolah Menengah Atas,” Akuntabilitas Manaj. Pendidik., vol. 2, no. 1, pp. 12-13, 2014. 